\section{Research methodology applied in a review of preservation management training}

\author{
Stella Thebridge
}

\section{The Author}

Stella Thebridge is a Research Fellow at the Centre for Information Research (CIRT),

University of Central England in Birmingham (UCE).

E-mail: stella.thebridge@uce.ac.uk

\section{The Occasion}

A recent Library and Information Commission funded study looked at the availability of training for preservation management in institutions across the libraries, archives and museums sectors. The study arose because of a perception among preservation specialists and practitioners that training was being carried out in a variety of institutions across a range of sectors, with little co-ordination. The project was undertaken by staff at the University of Central England in Birmingham. Dr. Graham Matthews was the Project Head and Stella Thebridge the Project Researcher.

\begin{abstract}
A recent research project funded by Resource under the auspices of the National Preservation Office reviewed the provision of training for preservation management across the libraries, archives and museums sectors. The methodology of literature searching, combined with an invitation to representative institutions from all the sectors to contribute information, showed the usefulness of a 'broad-brush' approach in eliciting a reliable amount of data about the range of training available, without the need for a large-scale questionnaire.
\end{abstract}

\section{Acknowledgements}

The National Preservation Office (NPO) is a focal point for libraries and archives working in the area of preservation, and had a key role throughout the project through representation on the project's Advisory Panel. This Panel also comprised preservation and training specialists from libraries, archives and museums.

\section{Introduction}

The thrust of the research is reflected in the five chapters of the project report (Thebridge and Matthews 2000) which include a literature review, training review and a list of trainers and resources. The report deals in detail with definitions, and the extensive literature review looks at training since the Ratcliffe Report (1984). It draws on resources from Europe and North America, as well as the UK, and offers a wide-ranging list of printed material, websites and key organisations.

\section{Research methodology}

The timescale for the project was six months, parttime, which allowed for a 'broad-brush' approach in surveying training provision.

It was agreed at the outset by the research team and the Advisory Panel that a formal blanket survey by questionnaire across all sectors would not be productive. Previous work in this area, notably the study by Feather, Matthews and Eden on preservation practice and policy in libraries in 1993 , (Feather et al, 1996) had already established a broad view of preservation management training activity in libraries. Feather and Eden's complementary study which surveyed 290 archives and record offices (1997) had established that training in preservation was more prevalent in archivesoriented institutions than in traditional libraries and information centres. As both surveys included questions about training, it was felt by the team conducting this project that a survey of all libraries, archives and museums at this stage would be at best unanswered by the vast majority and at worst deeply resented. Moreover, the information required was unlikely to lend itself to quantitative analysis, as it was envisaged that examples of training would show some variety between institutions and sectors.

The team undertaking this research therefore identified target groups where they would like responses about levels of activity in the area of training for preservation management, and these were as follows: 
Research methodology applied in a review . Stella Thebridge

\section{Type}

- companies

- conservators

- educational institutions

- heritage organisations

- library consortia

- professional associations

- public libraries with archives

- Record Offices

- training co-operatives

- training organisations

In all categories a selection of institutions was contacted. There was no intention to make statistical comparisons and therefore a representative sample was not sought. Rather the researchers wanted to build a picture of the kinds of activity going on, possible gaps in provision and to make recommendations for ways of developing training in this sphere. General invitations to respond to the request for information were issued via professional journals (Library Association Record, Managing Information) and e-mail discussion lists (lis-publibs, lis-rarebooks, nra-archives), as well as by word of mouth. Pro formas were also issued to all delegates to the NPO Seminar in October 1999 (for details see NPO, 2000).

\section{Review data}

The pro forma requested information under the following broad headings:

- In-house training

- External training

- Organisations/consultants used to conduct training in the respondent's institution

- Resources (full details of training packs, printed materials, videos, organisations, websites which respondents had found useful.)

An accompanying information sheet outlined the project details and defined terms used in the project. Use of the pro forma was optional, and it was not available on email or in journals except on request. Its intention was merely to focus respondents'
Library \& Information Research News (LIRN) Volume 24 - Number 78 - Winter 2000

\section{Example}

binders; disaster specialists

selected from the Museums \& Galleries

Commission's Conservation Register

library schools, specialist colleges

National Trust

regional groups, subject groupings

Aslib, Library Association, Society of

Archivists thoughts on the actual training offered and any resources used in preparing or delivering training. Some wrote letters instead, and many who returned the forms did not actually specify training resources used. Responses were received from every category in the range of targeted groups.

Some responses were followed up by telephone or interview. A visit was made to the Museums and Galleries Commission (now part of Resource), and also to the NPO to view resources with the Information Officer. A day in Oxford allowed for discussion with four preservation specialists in different parts of the University who offer training programmes.

Some library schools were targeted - that is, those that had responded to an informal email survey of all library schools by Professor John Feather, (Department of Information Science, Loughborough University) prior to his talk to the NPO Seminar in October 1999 (see NPO, 2000). Those giving positive responses were:

- Department of Information and Library Studies, Aberystwyth

- School of Information Studies, UCE in Birmingham

- School of Information Management, Brighton University

- School of Library, Archive and Information Studies, University College London

- Department of Information Science, Loughborough University 
Other higher education establishments with a specific archives/conservation orientation were contacted, and a written response was received from West Dean College in Chichester. Information about other courses was acquired from websites.

The responses were not quantified in terms of percentages of respondents, since the use of email discussion lists did not allow for a precise total figure to be allocated, and this was not the remit of the project. However, a total of 84 responses was received, with a spread of responses across sectors and types of institution, indicating the range of organisations engaged in preservation activity. Many of those who responded were enthusiastic about issues surrounding preservation, but their training was geared more to preservation awareness. While it was very useful to know of the provision of any preservation training, the overriding conclusion to be drawn from this data was that training in the area of preservation was still at the level of awareness rather than of management issues surrounding preservation.

The positive responses (49) identified preservation training in all the following types of organisation:

- Archives collections

- Area Museums Councils

- Conservation specialists

- Disaster salvage experts

- Heritage organisations

- Library schools

- National libraries and museums

- Professional groups

- Public libraries

- Record Offices

- University libraries

Within archives collections, museums and heritage organisations, the ethos of preservation management was well-established. As repositories for a range of materials, managers in these sorts of institution saw preservation as a core activity and management as essential to the survival of their collections. In libraries, the acceptance of preservation management was still varied. Where libraries housed archival collections, whether in public, academic or national institutions, there was usually more awareness of preservation issues, though preservation management might still be seen in these places as the exclusive remit of archives / local studies / special collections staff rather than a core management function of the whole library service.

Information for the training review was also drawn from events listings in professional journals across the sectors, and full details of these are in the research report.

\section{Outcomes of the review}

The report describes the list of training organisations and resources compiled during the review. This database has been passed to the NPO with the recommendation that its existence be widely advertised and course information be regularly updated and developed.

A list of references gives a wide-ranging picture of the books, journals, videos, websites and organisations relevant to preservation management training. This resource is reprinted in the proceedings of the NPO seminar (NPO, 2000) in order to be more widely available.

A key outcome of the review was the drafting of a list of skills for preservation managers. The report shows how this could be used to design training in preservation management by professional and regional umbrella groups for their particular interest groups. Ongoing discussion of this list is being encouraged by practitioners in all sectors involved in preservation issues.

\section{Conclusions and recommendations}

The research team concluded that training in the area of preservation is still principally about awareness rather than management issues. Recommendations of ways to develop the review's activities are amplified in the report, and include specific challenges to the following organisations:

- BAILER (the co-operative body of the library schools)

- Library Association

- NPO 
- Resource (comprising the former Library and Information Commission and Museums and Galleries Commission)

- Society of Archivists

- National Training Organisations, specifically CHNTO (Cultural Heritage) and ISNTO (Information Services).

Recommendations also included a second phase of the review to build on the draft skills list in order to produce guidance for developing preservation management training. Funding for this was subsequently not available.

The review shows how useful conclusions can be drawn from a non-representative study. In this case, the combined use of previous large-scale general studies in the sector, a comprehensive review of the literature and an invitation to a representative range of institutions to contribute information, yielded a wealth of data which was clearly indicative of preservation training across the whole sector. The review demonstrates that a small-scale project can be as effective in drawing together data in a closely defined area of activity as large-scale statistical sampling, which is both expensive and timeconsuming. The results of this review give a clear picture of preservation management training across not only information services but also training organisations and professional associations within the libraries, museums and archives sectors.

\section{References}

Feather, J, Matthews, G and Eden, P (1996)

Preservation management: policies and practices in British

libraries

Aldershot: Gower. ISBN: 0566076225

Feather, J and Eden, P (1997)

National preservation policy: policies and practices in archives and record offices

British Library. British Library Research and Innovation Report 43.

ISBN: $07 \mid 2333088$
NPO (2000) Training for preservation management: the next step. Proceedings of the National Preservation Office Annual Seminar 1999 and review of preservation management training in the UK and abroad: the main findings... ISBN: 0 7I23 47003 [available from NPO; tel: 0207 74I2 76I2; e-mail:npo@bl.uk]

Ratcliffe, FW and Patterson, D (1984)

Preservation policies and conservation in British libraries British Library. Library and Information Research Report 25. ISBN: 0 7I23 30356

Thebridge, $S$ and Matthews, G (2000)

Review of current preservation management training in the UK and abroad

Library and Information Commission Research Report 48. ISBN: I 902394240

[ordering details available at: www.lic.gov.uk/publications/researchreports/index.html] 